HOW TO DETERMINE THE OPTIMAL WRITE-OFF STRATEGY

FOR DEPRECIABLE THREE AND FIVE-YEAR PROPERTY

by

Ronald C. Clute

Taxpayers today are confronted with a complex array of interdependent methods that can be used to write-off depreciable property for income tax purposes. The range of options includes (1) immediate expensing which requires an adjustment to asset basis, (2) taking the full investment tax credit (ITC) $(10 \%$ or $6 \%$ ) and reducing asset basis by $50 \%$ of the credit claimed, (3) taking a reduced ITC ( $8 \%$ or $4 \%$ ) not requiring a reduction in asset basis, and/or (4) depreciating the asset under accelerated cost recovery system (ACRS). The authors' experience is that many taxpayers claim the reduced ITC with no expensing and depreciate the entire cost using ACRS because this approach minimizes record keeping costs and because it is often difficult to determine which combination of write-off methods yields the most tax benefits.

The purpose of this article is to demonstrate that the commonly used write-off method indicated above is almost never the optimal write-off method and to develop a series of tables that can be used to determine the optimal write-off method for three and five-year property. Ten, fifteen, and eighteen-year property are not included in this article because of their added complexity and space requirements. The tables are designed to provide a handy reference guide for tax advisors and taxpayers for determining the optimal write-off method for depreciable property and the value of tax benefits foregone in order to use the less complex $8 \%$ or $4 \%$ ITC rules with no expensing.

Numerous articles (see Evertt and Norton, Jordon, and Hobbs as examples) have been written that illustrate only the theoretically preferred write-off method for various classes of property. The difficulty with this approach is that the method generally theoretically preferred and the method that is best for a particular taxpayer are often not one in the same. The reason for this is that record keeping costs differ significantly among taxpayers as well as among write-off methods and this has an effect on the choice of write-off methods. This fact is not considered in the articles mentioned above or any other articles the authors have seen. Consequently, this article also includes the present value of the tax benefits that would have to be given up in order to use the commonly used less complex write-off method. The taxpayer merely has to compare the present value of the increased tax benefits to the present value of the increased record keeping costs associated with using the more complex write-off methods recommended in the tables to determine which method is best for his particular situation.

\title{
Mechanics of the Various Write-off Methods
}

Depreciable property may be expensed immediately, rather than capitalizing and subsequently depreciating the asset. The annual limitation on the amount expensed is currently set at $\$ 5,000$. A further limitation is that 
the expensed portion of asset cost cannot be utilized to claim as ITC or ACRS depreciation deductions. For example, an asset costing $\$ 12,500$ can be immediately expensed to the extent of $\$ 5,000$ with the remaining $\$ 7,500$ of cost used for claiming an ITC and ACRS depreciation deductions.

An: ITC may be taken equal to $10 \%$ of the capitalized cost (after reduction for expensing) of a depreciable asset for the year in. which it is placed into service as five, ten, fifteen, or eighteen-year ACRS class property. The ITC rate is $6 \%$ for three-year ACRS class property. Generally, all depreciable property other than buildings and their structural components qualify for an ITC. The depreciable basis of the property must be reduced by $50 \%$ of the ITC claimed if the full ITC is taken. The reduced ITC rules are explained below. Continuing from the prior example, a five-year ACRS class asset costing $\$ 12,500$ with $\$ 5,000$ of the cost expensed will yield a $\$ 750$ ITC $(\$ 12,500-$ $\$ 5,000=\$ 7,500 \times \cdot 10=\$ 750)$. The ACRS depreciable basis of the asset must be reduced by $\$ 375(.50 \times \$ 750 \mathrm{ITC})$ and is now $\$ 7,125(\$ 12,500-\$ 5,000-\$ 375$ $=\$ 7,125)$.

A reduced ITC may be taken equal to $8 \%$ for five, ten, fifteen, or eighteenyear property (4\% for three-year property) which does not require a basis reduction. Referring to the previous example, the ITC will be $\$ 600(\$ 7,500 \mathrm{x}$ .08), rather than $\$ 750$. The depreciable basis will remain $\$ 7,500$. Under either method the maximum credit allowed in any given year is $100 \%$ of the First $\$ 25,000$ of tax liability and $85 \%$ of any tax liability exceeding $\$ 25,000$. Although there is no limit to the dollar amount of new property qualifying for the ITC, the cost of used property is currently limited to \$125,000 per year until 1987 .

The final option is to capitalize and subsequently depreciate the asset using ACRS rules. These rules currently place all qualifying property into three, five, ten, fifteen or eighteen-year property. Three-year property generally includes automobiles, light duty trucks, and short lived personal property; five-year property generally includes most other equipment; ten-year property is generally restricted to short lived public utility property; fifteen-year property includes. Iong lived public utility property; and eighteen-year property includes all non-public utility real property. ACRS rules require taking a prescribed percentage of asset cost (after reduction for expensing and ITC) as a depreciation deduction.

How to Use the Tables

A separate table has been developed for three and five-year ACRS class property. Determining the optimal write-off method from these tables requires knowledge of the taxpayer's average marginal tax rate, cost of funds, and the asset's ACRS classification. In order to develop generalizations regarding the present value of future tax benefits for the various write-off methods, an estimate must be made of the average marginal tax rate covering the entire life of the asset in question. By examining prior years' taxes, most taxpayers should be able to estimate future tax rates within a certain range. An estimated tax rate with a plus or minus $5 \%$ margin of error is adequate for most purposes. As an example, a tax rate of $30 \%$ can be used if the range of future average marginal tax rates is thought to be between $25 \%$ and $35 \%$. 
The cost of funds technically is the interest rate that can be earned on tax savings when those savings are invested in a risk free investment. Additionally, the interest rate must be an after tax interest rate because taxes, like all other expenses associated with an investment, must be deducted in order to determine the net return from the investment. For example, assume that the tax savings related to the purchase of a particular asset can be invested at $8.6 \%$ in government securities or an insured money market account. If the average marginal tax rate is assumed to be approximately $30 \%$, the after tax rate of return will be $6 \%[.086 \times(1-.30)=.06]$.

The determination of an asset's ACRS classification should not present a problem. The classification guidelines are outlined in general terms in this article and are available in extensive detail from many other sources.

\section{Example 1}

Assume that three-year property costing $\$ 15,000$ is purchased by a taxpayer with an average marginal tax rate of $20 \%$ and an after tax rate of return of $12 \%$. Referring to Table I for an interest rate of $12 \%$ and a tax rate of $20 \%$, the optimal write-off method is to forego expensing, take a $6 \%$ ITC and depreciate the balance of $\$ 14,550$ [ $\$ 15,000-\left(\frac{1}{4} \times\right.$ x $\$ 900$ ITC $\left.)\right]$ using ACRS. Opting for the reduced $4 \%$ ITC without expensing would reduce the present value of the future tax benefits by $\$ 208$. The no discounting column ( $0 \%$ interest rate) indicates that the actual out-of-pocket cost of taking a reduced $4 \%$ ITC without expensing rather than the optimal write-off method is $\$ 210$. The $\$ 208$ figure can be compared to the increase in estimated record keeping costs (in present value terms) associated with a $\$ 450$ basis adjustment to determine which method is preferred.

Example 2

Assume that five-year property costing $\$ 100,000$ is purchased by a taxpayer who has an average marginal tax rate of $45 \%$ and an after tax rate of return of 15\%. Referring to Table II for an after tax interest rate of $15 \%$ and an average marginal tax rate of $45 \%$, the theoretically preferred write-off method is to expense $\$ 5,000$ of asset cost, then take the full $10 \%$ ITC, and finally depreciate the balance of the depreciable cost using ACRS. Using the optimal method of $10 \%$ ITC with expensing rather than the easier $8 \%$ ITC without expensing will yield $\$ 395$ more in tax benefits in present value terms. If the additional record keeping costs associated, with expensing and the 10\% ITC and the related basis reduction requirements are less than $\$ 395$ (in present value terms), then the optimal method indicated in the table is the one this taxpayer should use. Anticipated record keeping costs greater than \$395 suggests that from a cost benefit point of view this taxpayer should use the less costly $8 \%$ ITC without expensing method.

\section{Example 3}

Assume that five-year property costing $\$ 10,000$ is purchased by a taxpayer who has an average marginal tax rate of $15 \%$ and an after tax rate of return of 


\section{TABLE I}

A Table of Optimal Write-off Methods and Net Advantage of the Optimal Method Over the Reduced ITC Without Expensing Method Based on a \$15,000 Cost for Three-year Property

\begin{tabular}{|c|c|c|c|c|c|c|c|c|c|}
\hline $\begin{array}{l}\text { Tax } \\
\text { Rate }\end{array}$ & $0 \%$ & $3 \%$ & $6 \%$ & Intere & = Rates & $15 \%$ & $18 \%$ & $21 \%$ & $24 \%$ \\
\hline $5 \%$ & $\begin{array}{l}\$ 278 \\
6 \% \text { No }\end{array}$ & $\begin{array}{l}\$ 274 \\
6 \% \text { No }\end{array}$ & $\begin{array}{l}\$ 271 \\
6 \% \text { No }\end{array}$ & $\begin{array}{l}\$ 268 \\
6 \% \text { No }\end{array}$ & $\begin{array}{l}\$ 265 \\
6 \% \text { No }\end{array}$ & $\begin{array}{l}\$ 262 \\
6 \% \text { No }\end{array}$ & $\begin{array}{l}\$ 259 \\
6 \% \text { No }\end{array}$ & $\begin{array}{l}\$ 256 \\
6 \% \text { No }\end{array}$ & $\begin{array}{l}\$ 253 \\
6 \% \text { No }\end{array}$ \\
\hline $10 \%$ & $\begin{array}{c}255 \\
6 \% \text { No }\end{array}$ & $\begin{array}{c}253 \\
6 \% \text { No }\end{array}$ & $\begin{array}{c}250 \\
6 \% \text { No }\end{array}$ & $\begin{array}{c}248 \\
6 \% \text { No }\end{array}$ & $\begin{array}{c}246 \\
6 \% \text { No }\end{array}$ & $\begin{array}{c}244 \\
6 \% \text { No }\end{array}$ & $\begin{array}{c}241 \\
6 \% \text { No }\end{array}$ & $\begin{array}{c}239 \\
6 \% \text { No }\end{array}$ & $\begin{array}{c}237 \\
6 \% \text { No }\end{array}$ \\
\hline $15 \%$ & $\begin{array}{c}233 \\
6 \% \text { No }\end{array}$ & $\begin{array}{c}231 \\
6 \% \text { No }\end{array}$ & $\begin{array}{c}230 \\
6 \% \text { No }\end{array}$ & $\begin{array}{c}229 \\
6 \% \text { No }\end{array}$ & $\begin{array}{c}227 \\
6 \% \text { No }\end{array}$ & $\begin{array}{c}226 \\
6 \% \text { No }\end{array}$ & $\begin{array}{c}224 \\
6 \% \text { No }\end{array}$ & $\begin{array}{c}223 \\
6 \% \text { No }\end{array}$ & $\begin{array}{c}221 \\
6 \% \text { No }\end{array}$ \\
\hline $20 \%$ & $\begin{array}{c}210 \\
6 \% \text { No }\end{array}$ & $\begin{array}{c}210 \\
6 \% \text { No }\end{array}$ & $\begin{array}{c}210 \\
6 \% \text { No }\end{array}$ & $\begin{array}{c}210 \\
6 \% \text { No }\end{array}$ & $\begin{array}{c}208 \\
6 \% \text { No }\end{array}$ & $\begin{array}{c}208 \\
6 \% \text { No }\end{array}$ & $\begin{array}{c}207 \\
6 \% \text { No }\end{array}$ & $\begin{array}{c}206 \\
6 \% \text { No }\end{array}$ & $\begin{array}{c}205 \\
6 \% \text { No }\end{array}$ \\
\hline $25 \%$ & $\begin{array}{c}188 \\
6 \% \text { No }\end{array}$ & $\begin{array}{c}188 \\
6 \% \text { No }\end{array}$ & $\begin{array}{c}189 \\
6 \% \text { No }\end{array}$ & $\begin{array}{c}189 \\
6 \% \text { No }\end{array}$ & $\begin{array}{c}189 \\
6 \% \text { No }\end{array}$ & $\begin{array}{c}189 \\
6 \% \text { No }\end{array}$ & $\begin{array}{c}189 \\
6 \% \text { No }\end{array}$ & $\begin{array}{c}189 \\
6 \% \text { No }\end{array}$ & $\begin{array}{c}189 \\
6 \% \text { No }\end{array}$ \\
\hline $30 \%$ & $\begin{array}{c}165 \\
6 \% \text { No }\end{array}$ & $\begin{array}{c}167 \\
6 \% \text { No }\end{array}$ & $\begin{array}{c}168 \\
6 \% \text { No }\end{array}$ & $\begin{array}{c}170 \\
6 \% \text { No }\end{array}$ & $\begin{array}{c}171 \\
6 \% \text { No }\end{array}$ & $\begin{array}{c}171 \\
6 \% \text { No }\end{array}$ & $\begin{array}{c}172 \\
6 \% \text { No }\end{array}$ & $\begin{array}{l}183 \\
6 \% \text { Yes }\end{array}$ & $\begin{array}{l}209 \\
6 \% \text { Yes }\end{array}$ \\
\hline $35 \%$ & $\begin{array}{c}143 \\
6 \% \text { No }\end{array}$ & $\begin{array}{c}145 \\
6 \% \text { No }\end{array}$ & $\begin{array}{c}148 \\
6 \% \text { No }\end{array}$ & $\begin{array}{c}150 \\
6 \% \text { No }\end{array}$ & $\begin{array}{c}152 \\
6 \% \text { No }\end{array}$ & $\begin{array}{c}153 \\
6 \% \text { No }\end{array}$ & $\begin{array}{l}180 \\
6 \% \text { Yes }\end{array}$ & $\begin{array}{c}214 \\
6 \% \text { Yes }\end{array}$ & $\begin{array}{c}244 \\
6 \% \text { Yes }\end{array}$ \\
\hline $40 \%$ & $\begin{array}{c}120 \\
6 \% \text { No }\end{array}$ & $\begin{array}{c}124 \\
6 \% \text { No }\end{array}$ & $\begin{array}{c}127 \\
6 \% \text { No }\end{array}$ & $\begin{array}{c}130 \\
6 \% \text { No }\end{array}$ & $\begin{array}{c}133 \\
6 \% \text { No }\end{array}$ & $\begin{array}{l}164 \\
6 \% \text { Yes }\end{array}$ & $\begin{array}{l}206 \\
6 \% \text { Yes }\end{array}$ & $\begin{array}{l}244 \\
6 \% \text { Yes }\end{array}$ & $\begin{array}{c}279 \\
6 \% \text { Yes }\end{array}$ \\
\hline $45 \%$ & $\begin{array}{c}98 \\
6 \% \text { No }\end{array}$ & $\begin{array}{c}103 \\
6 \% \text { No }\end{array}$ & $\begin{array}{c}107 \\
6 \% \text { No }\end{array}$ & $\begin{array}{c}111 \\
6 \% \text { No }\end{array}$ & $\begin{array}{l}133 \\
6 \% \text { Yes }\end{array}$ & $\begin{array}{l}185 \\
6 \% \text { Yes }\end{array}$ & $\begin{array}{l}232 \\
6 \% \text { Yes }\end{array}$ & $\begin{array}{l}275 \\
6 \% \text { Yes }\end{array}$ & $\begin{array}{c}313 \\
6 \% \text { Yes }\end{array}$ \\
\hline $50 \%$ & $\begin{array}{c}75 \\
6 \% \text { No }\end{array}$ & $\begin{array}{c}81 \\
6 \% \text { No }\end{array}$ & $\begin{array}{c}86 \\
6 \% \text { No }\end{array}$ & $\begin{array}{c}91 \\
6 \% \text { No }\end{array}$ & $\begin{array}{l}148 \\
6 \% \text { Yes }\end{array}$ & $\begin{array}{c}206 \\
6 \% \text { Yes }\end{array}$ & $\begin{array}{c}258 \\
6 \% \text { Yes }\end{array}$ & $\begin{array}{l}305 \\
6 \% \text { Yes }\end{array}$ & $\begin{array}{l}348 \\
6 \% \text { Yes }\end{array}$ \\
\hline
\end{tabular}

"6\%" indicates that the full ITC is recommended.

"Yes" indicates that the maximum expensing allowance is recommended.

"No" indicates that expensing is not recommended. 
TABLE II

A Table of Optimal Write-off Methods and Net

Advantage of the Optimal Method Over the Reduced ITC Without

Expensing Method Based on a $\$ 100,000$ Cost for Five-year Property

\begin{tabular}{|c|c|c|c|c|c|c|c|c|c|}
\hline \multirow{2}{*}{$\begin{array}{l}\text { Tax } \\
\text { Rate }\end{array}$} & \multirow[b]{2}{*}{$0 \%$} & \multicolumn{6}{|c|}{ Interest Rates } & \multirow[b]{2}{*}{$21 \%$} & \multirow[b]{2}{*}{$24 \%$} \\
\hline & & $3 \%$ & $6 \%$ & $9 \%$ & $12 \%$ & $15 \%$ & $18 \%$ & & \\
\hline $5 \%$ & $\begin{array}{l}\$ 1,750 \\
10 \% \text { No }\end{array}$ & $\begin{array}{l}\$ 1,739 \\
10 \% \text { No }\end{array}$ & $\begin{array}{l}\$ 1,727 \\
10 \% \text { No }\end{array}$ & $\begin{array}{l}\$ 1,715 \\
10 \% \text { No }\end{array}$ & $\begin{array}{l}\$ 1,702 \\
10 \% \text { No }\end{array}$ & $\begin{array}{l}\$ 1,688 \\
10 \% \text { No }\end{array}$ & $\begin{array}{l}\$ 1,675 \\
10 \% \text { No }\end{array}$ & $\begin{array}{l}\$ 1,661 \\
10 \% \text { No }\end{array}$ & $\begin{array}{l}\$ 1,647 \\
10 \% \text { No }\end{array}$ \\
\hline $10 \%$ & $\begin{array}{r}1,500 \\
10 \% \text { No }\end{array}$ & $\begin{array}{r}1,507 \\
10 \% \text { No }\end{array}$ & $\begin{array}{r}1,512 \\
10 \% \text { No }\end{array}$ & $\begin{array}{r}1,514 \\
10 \% \text { No }\end{array}$ & $\begin{array}{r}1,513 \\
10 \% \text { No }\end{array}$ & $\begin{array}{r}1,511 \\
10 \% \text { No }\end{array}$ & $\begin{array}{r}1,508 \\
10 \% \text { No }\end{array}$ & $\begin{array}{r}1,504 \\
10 \% \text { No }\end{array}$ & $\begin{array}{r}1,498 \\
10 \% \text { No }\end{array}$ \\
\hline $15 \%$ & $\begin{array}{r}1,250 \\
10 \% \text { No }\end{array}$ & $\begin{array}{r}1,276 \\
10 \% \text { No }\end{array}$ & $\begin{array}{r}1,296 \\
10 \% \text { No }\end{array}$ & $\begin{array}{r}1,313 \\
10 \% \text { No }\end{array}$ & $\begin{array}{r}1,325 \\
10 \% \text { No }\end{array}$ & $\begin{array}{r}1,335 \\
10 \% \text { No }\end{array}$ & $\begin{array}{r}1,342 \\
10 \% \text { No }\end{array}$ & $\begin{array}{r}1,347 \\
10 \% \text { No }\end{array}$ & $\begin{array}{r}1,350 \\
10 \% \text { No }\end{array}$ \\
\hline $20 \%$ & $\begin{array}{r}1,000 \\
10 \% \text { No }\end{array}$ & $\begin{array}{r}1,044 \\
10 \% \text { No }\end{array}$ & $\begin{array}{r}1,081 \\
10 \% \text { No }\end{array}$ & $\begin{array}{r}1,112 \\
10 \% \text { No }\end{array}$ & $\begin{array}{r}1,137 \\
10 \% \text { No }\end{array}$ & $\begin{array}{r}1,158 \\
10 \% \text { No }\end{array}$ & $\begin{array}{r}1,175 \\
10 \% \text { No }\end{array}$ & $\begin{array}{r}1,189 \\
10 \% \text { No }\end{array}$ & $\begin{array}{r}1,201 \\
10 \% \text { No }\end{array}$ \\
\hline $25 \%$ & $\begin{array}{r}750 \\
10 \% \text { No }\end{array}$ & $\begin{array}{r}813 \\
10 \% \text { No }\end{array}$ & $\begin{array}{r}886 \\
10 \% \text { No }\end{array}$ & $\begin{array}{r}911 \\
10 \% \text { No }\end{array}$ & $\begin{array}{r}949 \\
10 \% \text { No }\end{array}$ & $\begin{array}{r}981 \\
10 \% \text { No }\end{array}$ & $\begin{array}{r}1,009 \\
10 \% \text { No }\end{array}$ & $\begin{array}{r}1,032 \\
10 \% \text { No }\end{array}$ & $\begin{array}{r}1,052 \\
10 \% \text { No }\end{array}$ \\
\hline $30 \%$ & $\begin{array}{r}500 \\
10 \% \text { No }\end{array}$ & $\begin{array}{r}581 \\
10 \% \text { No }\end{array}$ & $\begin{array}{r}650 \\
10 \% \text { No }\end{array}$ & $\begin{array}{r}710 \\
10 \% \text { No }\end{array}$ & $\begin{array}{r}761 \\
10 \% \text { No }\end{array}$ & $\begin{array}{r}805 \\
10 \% \text { No }\end{array}$ & $\begin{array}{r}842 \\
10 \% \text { No }\end{array}$ & $\begin{array}{c}888 \\
10 \% \text { Yes }\end{array}$ & $\begin{array}{c}953 \\
10 \% \text { Yes }\end{array}$ \\
\hline $35 \%$ & $\begin{array}{r}250 \\
10 \% \text { No }\end{array}$ & $\begin{array}{r}349 \\
10 \% \text { No }\end{array}$ & $\begin{array}{r}435 \\
10 \% \text { No }\end{array}$ & $\begin{array}{r}509 \\
10 \% \text { No }\end{array}$ & $\begin{array}{r}572 \\
10 \% \text { No }\end{array}$ & $\begin{array}{r}628 \\
10 \% \text { No }\end{array}$ & $\begin{array}{c}719 \\
10 \% \text { Yes }\end{array}$ & $\begin{array}{c}809 \\
10 \% \text { Yes }\end{array}$ & $\begin{array}{c}887 \\
10 \% \text { Yes }\end{array}$ \\
\hline $\begin{array}{l}40 \% \\
8 \% \text { or }\end{array}$ & $\begin{array}{r}-0- \\
10 \% \text { No }\end{array}$ & $\begin{array}{r}118 \\
10 \% \text { No }\end{array}$ & $\begin{array}{r}219 \\
10 \% \text { No }\end{array}$ & $\begin{array}{r}307 \\
10 \% \text { No }\end{array}$ & $\begin{array}{r}384 \\
10 \% \text { No }\end{array}$ & $\begin{array}{c}506 \\
10 \% \text { Yes }\end{array}$ & $\begin{array}{c}625 \\
10 \% \text { Yes }\end{array}$ & $\begin{array}{c}729 \\
10 \% \text { Yes }\end{array}$ & $\begin{array}{c}821 \\
10 \% \text { Yes }\end{array}$ \\
\hline $45 \%$ & $\begin{array}{l}-0- \\
8 \% \text { No }\end{array}$ & $8 \%$ No & $\begin{array}{r}4 \\
10 \% \text { No }\end{array}$ & $\begin{array}{r}106 \\
10 \% \text { No }\end{array}$ & $\begin{array}{c}240 \\
10 \% \text { Yes }\end{array}$ & $\begin{array}{c}395 \\
10 \% \text { Yes }\end{array}$ & $\begin{array}{c}530 \\
10 \% \text { Yes }\end{array}$ & $\begin{array}{c}650 \\
10 \% \text { Yes }\end{array}$ & $\begin{array}{c}756 \\
10 \% \text { Yes }\end{array}$ \\
\hline $50 \%$ & $8 \%$ No & $8 \%$ No & $8 \%$ No- & $\begin{array}{c}1 \\
8 \% \text { Yes }\end{array}$ & $\begin{array}{c}109 \\
10 \% \text { Yes }\end{array}$ & $\begin{array}{c}283 \\
10 \% \text { Yes }\end{array}$ & $\begin{array}{c}436 \\
10 \% \text { Yes }\end{array}$ & $\begin{array}{c}571 \\
10 \% \text { Yes }\end{array}$ & $\begin{array}{c}690 \\
10 \% \text { Yes }\end{array}$ \\
\hline
\end{tabular}

"10\%" indicates that the full 10\% ITC is recommended.

" $8 \%$ " indicates that the reduced $8 \%$ ITC is recommended.

"Yes" indicates that the maximum expensing allowance is recommended.

"No" indicates that expensing is not recommended. 
15\%. The optimal write-off method indicated in Table II is to forego expensing, take the full ITC of $10 \%$ and depreciate the balance of $\$ 9,500\left[\$ 10,000-\left(\frac{1}{2} \mathrm{x}\right.\right.$ $\$ 1,000)]$. The fact that the asset cost $\$ 10,000$ rather than the $\$ 100,000$ used to develop the table has no effect on the appropriate rule indicated in either table. In this case the net advantage of $\$ 1,335$ must be multiplied by $10 \%$ since the asset in question cost only $10 \%$ of the asset cost used to develop this table. When expensing is not indicated, the net advantage is always a pro rata function of asset cost to the cost used to develop the table. In other words, the net advantage for a $\$ 45,000$ asset is $45 \%$ of the dollar amount found in Table II. The net advantage in Table I must be multiplied by $300 \%$ for an asset costing $\$ 45,000$. When expensing is indicated, this pro rata relationship for the dollar amount of advantage is only valid for assets costing around $\$ 15,000$ for Table I and $\$ 75,000$ or more for Table II. For five-year property costing less than $\$ 75,000$ (other than $\$ 15,000$ for three-year) when expensing is recommended, the dollar amount of the net advantage is distorted by the effect of the large amount expensed relative to asset cost. The appropriate write-off method indicated in the tables is never affected by asset cost.

\section{Example 4}

Assume that five-year property with an aggregate cost of $\$ 200,000$ is acquired by a taxpayer with an average marginal tax rate of $50 \%$ and an after tax rate of return of $9 \%$. The theoretically preferred write-off method indicated in Table II is to expense $\$ 5,000$ of cost and take a reduced ITC of $8 \%$ and depreciate the remaining balance. The maximum benefit in this case that can be derived from keeping track of which assets were expensed and which ones were not is a mere $\$ 2.00$. On the other hand, the cost associated with that $\$ 2.00$ benefit could very likely be in the hundreds of dollars. Clearly, knowing only the theoretically preferred write-off method does not always provide the taxpayer with the best strategy as can be seen from this example.

\section{Development of the Tables}

The tables are developed by computing the present value of all tax benefits for all combinations of tax rates and interest rates in the tables assuming (1) no expensing, 10\% ITC, and ACRS depreciation, (2) expensing, 10\% ITC, and ACRS depreciation, (3) no expensing, 8\% ITC, and ACRS depreciation and (4) expensing, $8 \%$ ITC, and ACRS depreciation. In the case of three-year property, $6 \%$ and $4 \%$ are used. The above computations are repeated for assets costing $\$ 5,000, \$ 7,500, \$ 10,000, \$ 15,000, \$ 20,000, \$ 25,000, \$ 50,000, \$ 75,000, \$ 100,000$, and $\$ 200,000$. Tables I and II, however, are based on assets costing $\$ 15,000$ and $\$ 100,000$, respectively. The write-off method yielding the highest present value for each combination of tax rates is the optimal method and is found in the tables. The net advantage listed in the tables is the difference between the present value of the tax benefits using the optimal write-off method and the present value of the tax benefits using, the reduced ITC with no expensing.

The present value calculations are based on mid-year factors since most taxpayers realize tax benefits throughout the year making mid-year factors more appropriate than either beginning or end of the year factors. Quarterly factors, 
although theoretically preferred, were not utilized because of economy of computation and because their use has only a marginal effect on the dollar amount of net advantage and choice of methods. The date of asset acquisition is assumed to be at the beginning of the tax year. The optimal write-off method is not affected by mid-year acquisitions, although the dollar amount of net advantage will be somewhat higher. All calculations are based on the assumptions of no depreciation recapture, ITC recapture, taxable gain or loss on disposal, or ITC carryover.

If multiple assets are acquired representing more than one ACRS class, the expensing limitation may force the taxpayer to choose which asset to expense. In that event, the present value of tax benefits is maximized when the longer ACRS class life asset is expensed and the shorter ACRS class life asset is depreciated. A taxpayer acquiring multiple assets may also need to determine the appropriate ITC method when expensing is recommended but no longer an option. This is quite likely to occur since $\$ 5,000$ is the maximum expensing a taxpayer is allowed per year. In that case, the tables provide the correct answer as to which ITC method to use. The dollar amount of net advantage, of course, must be disregarded if expensing is indicated but is not available because of the $\$ 5,000$ limitation. If expensing is not indicated in the tables and is not available, the tables provide the correct write-off method and net advantage.

\section{References}

1. Everett, J.O., and C.L. Norton, "Key factors Aid in Selecting the Optimal Write-off Method for Section 38 Property, "The Journal of Taxation (February 1982), pp. 93-94.

2. Jordan, W.F., "Capital Recovery Options Under the Economic Recovery Tax Act of 1981: An Analysis of Comparative Benefits," The Journal of the American Taxation Association (Winter 1982), pp. 5-14.

3. Jordan, W.F., "Capital Recovery Options: A Response and a Note on Changes Resulting from The Tax Equity and Fiscal Responsibility Act of 1982 (TEFRA)," The Journal of the American Taxation Association (July 1983), pp. 63-68.

4. Hobbs, J.B. "How to Select the Optimum Tax Recovery Method for Depreciable Property," The Journal of Taxation (July 1983), pp. 48-52.

5. Norton, C.L. and J.0. Everett, "An Extension of Jordon's Analysis of Section 179 Property," The Journal of the American Taxation Association (Fal1 1983), pp. 60-62. 